\title{
Risicogedrag en het wereldwijde web De invloed van gezin en samenleving op het online risicogedrag van adolescenten vanuit een Europees perspectief
}

\author{
Natascha Notten ${ }^{1}$
}

\section{Summary}

Risk behavior and the World Wide Web

The impact of parents and society on adolescents' risky online behavior from a European perspective

This study explores the relation between adolescents' risky online behavior, their parents' internet mediation and the prevalence of internet use in a country. Using the EU Kids Online dataset, including information on 15,415 adolescents in 25 countries, this study found that adolescents from lower educated and single-parent households are more likely to engage in risky online behavior. Furthermore, parental social internet mediation and especially rules restricting children's internet use appear to be effective ways to reduce risk-taking by adolescents online. Parental monitoring seems to increase when adolescents are risky online. The level of modernization of a country seems to have no effect on adolescents' participation in risky online activities. However, in more digitalized societies, parental social mediation seems less decisive in reducing risky behavior of adolescents online. Applying restrictions on internet use in the family home is an effective way to curb young people's risky online behavior, regardless of a country's level of internet diffusion.

\section{Inleiding}

Internet biedt kinderen en jongeren een wereld aan mogelijkheden, maar het brengt ook risico's met zich mee. Het vertonen van online risicogedrag - zoals het online prijsgeven van persoonlijke informatie of het ontmoeten van vreemden - is een belangrijke voorspeller van negatieve ervaringen. Voorbeelden hiervan zijn blootstelling aan onwenselijke 
inhoud of het terechtkomen in situaties waarbij seksuele intimidatie en privacyschendingen een rol spelen (Hasebrink e.a., 2008; Lobe e.a., 2011; Livingstone e.a., 2011b). Natuurlijk leidt online risicogedrag niet altijd tot negatieve ervaringen of emotionele schade (Leung \& Lee, 2011). De mogelijke negatieve consequenties van online risicogedrag zijn echter ingrijpend en daarom voor ouders, opvoeders en beleidsmakers een bron van zorg en een belangrijk punt van aandacht.

Niet alle kinderen vertonen online risicogedrag. De meeste kinderen en jongeren zijn niet in ernstige mate betrokken bij riskante online activiteiten (Livingstone e.a., 2011b). Maar ook als ze dat wel zijn, verschilt hun gedrag in intensiteit en frequentie. De sociale omgeving vormt een belangrijke indicator voor het media- en internetgebruik van kinderen. Zo verschilt de mate waarin kinderen online actief zijn en de activiteiten die ze online ondernemen tussen gezinnen (Livingstone \& Helsper, 2010; Notten e.a., 2009). De oorzaak hiervan kan liggen in verschillen in gezinssamenstelling, bijvoorbeeld een- versus tweeoudergezinnen, en de sociaaleconomische achtergrond van de ouders. Ook bestaan er sociale verschillen in wijzen waarop ouders hun kinderen opvoeden met internetgebruik. Ouders verschillen in hun eigen ervaring met internet, hun begeleiding van het internetgebruik van hun kinderen en ook is de mate waarin kinderen thuis toegang hebben tot internet verschillend (Lee, 2013; Livingstone \& Helsper, 2008; Notten \& Kraaykamp, 2009b).

Naast het ouderlijk gezin heeft ook de wijdere sociale context, ofwel de samenleving waarin men opgroeit, invloed op het online gedrag van jongeren. Algemene computervaardigheden, online communicatievaardigheden en het gebruik ervan verschillen niet alleen tussen individuen, maar ook tussen landen (DiMaggio e.a., 2004; Hargittai, 2010; Kirwil, 2009; Notten e.a., 2009). Eerdere studies wijzen uit dat het niveau van digitale ontwikkeling in een land in verband staat met meer risico's online (Hasebrink e.a., 2008; Lobe e.a., 2011), maar ook met de internetbegeleiding die ouders hun kinderen bieden (Kirwil, 2009). Het is daarom belangrijk te onderzoeken hoe de mate van digitale ontwikkeling, ofwel internetverspreiding, in een land van invloed kan zijn op het online risicogedrag van adolescenten en op de opvoedstrategieën die ouders toepassen om dit gedrag te beperken.

Uit eerder onderzoekt blijkt dat veel tijd doorbrengen voor een beeldscherm en blootstelling aan schadelijke media-inhoud negatief kan doorwerken op de ontwikkeling en het welbevinden van een kind. Veel televisiekijken bijvoorbeeld blijkt een belemmering te zijn voor de cognitieve ontwikkeling van kinderen, het kan agressief gedrag stimuleren en ook de kans op overwicht vergroten (Notten, Kraaykamp \& Tolsma, 2013; Valkenburg, 2004). Ook onderzoek naar internetgebruik toont herhaaldelijk aan dat er, naast positieve gevolgen, ook negatieve consequenties 
kleven aan internetgebruik. Zo blijkt dat veel tijd besteden aan sociale media en het veelvuldig spelen van (gewelddadige) online games een gezonde ontwikkeling van een kind in de weg kunnen staan (Fogel \& Nehmad, 2009; Valkenburg \& Peter, 2011).

Tegenwoordig zijn de meeste adolescenten online. Sociale netwerksites, zoals Facebook, zijn binnen korte tijd enorm populair geworden (Lenhart e.a., 2010), en adolescenten zijn experts op het gebied van online communiceren (Valkenburg \& Peter, 2011). Jongeren gaan echter ook vaak lichtzinnig te werk bij het produceren en gebruiken van online informatie (Deursen, Van Dijk \& Peeters, 2011; Fogel \& Nehmad, 2009; Walraven, Brand-Gruwel \& Boshuizen, 2009), hetgeen kan leiden tot negatieve online ervaringen (Görzig \& Ólafsson, 2013; Peter \& Valkenburg, 2006). Vergelijkend onderzoek naar specifiek online risicogedrag is schaars. In onderzoek naar online risico's wordt meestal geen onderscheid gemaakt tussen online risicogedrag en online risico-ervaring. Online risicogedrag verwijst naar een vrijwillige gedragskeuze, online risico-ervaringen daarentegen zijn doorgaans niet-intentioneel en mogelijk een consequentie van het vertoonde online risicogedrag.

Deze studie richt zich expliciet op individuele en contextuele factoren die online risicogedrag van adolescenten kunnen verklaren, vanuit een landenvergelijkend perspectief. Dit is gedaan op basis van gegevens afkomstig van het EU Kids Online II-project, waarbij gebruikgemaakt is van multiniveau-analyse. De algemene onderzoeksvraag is tweeledig: (i) In hoeverre is er een relatie tussen verschillen in gezinskenmerken, ouderlijke internetbegeleiding, de mate van internetverspreiding in een land en verschillen in online risicogedrag van adolescenten? (ii) In hoeverre wordt de relatie tussen ouderlijke internetbegeleiding en online risicogedrag van adolescenten beïnvloed door het niveau van internetverspreiding binnen een land? In moderne samenlevingen lijkt de rol van internet steeds belangrijker, zowel binnen het gezin als daarbuiten. Het vinden van antwoorden op de hier gestelde onderzoeksvragen is daarom relevant, voor zowel opvoeders als beleidsmakers.

\section{Theorie en hypothesen}

\section{I Gezinskenmerken en online risicogedrag}

Kinderen groeien op binnen een sociale context en het gezin waarin ze opgroeien heeft doorgaans de grootste invloed op hun ontwikkeling (Bandura, 1977; Bronfenbrenner, 1979). Er bestaan grote verschillen tussen gezinnen in tal van opzichten, en ouders verschillen in wat ze aan hun kinderen meegeven. Sommige ouders kunnen hun kinderen gunstige vaardigheden en hulpbronnen meegeven. In andere gezinnen 
gebeurt dit minder of laten ouders hun kinderen opgroeien in een mediaomgeving die eerder een negatieve dan positieve invloed heeft op de ontwikkeling van hun kinderen (D’Haenens, 2001; Hoeve e.a., 2009; Patterson, Debaryshe \& Ramsey, 1990; Notten \& Kraaykamp, 2009b). In dit onderzoek wordt daarom bekeken wat de invloed van de sociaaleconomische status (opleidingsniveau) en de gezinssamenstelling is op online risicogedrag van adolescenten.

In het algemeen beschikken hoger opgeleide ouders over meer gunstige cognitieve en culturele vaardigheden die zij kunnen overdragen op hun kinderen dan ouders met een lager opleidingsniveau (Bourdieu, 1984). Ook zijn hoger opgeleide ouders meer ervaren in het gebruik van informatieve en complexe digitale technologieën. Ze hebben meer oog voor de educatieve mogelijkheden van computers en internet, en ze beschikken over meer vaardigheden om de online activiteiten van hun kinderen te begeleiden (Clark, Demont-Heinrich \& Webber, 2005; Pasquier, 2001; Paus-Hasebrink e.a., 2013). Adolescenten met hoger opgeleide ouders zijn daarom waarschijnlijk beter geïnformeerde en vaardigere internetgebruikers, en zijn zich ook meer bewust van de risico's die internet met zich meebrengt (Livinstone \& Helsper, 2010; Notten et al., 2009). De verwachting is daarom dat adolescenten uit gezinnen met hoger opgeleide ouders minder online risicogedrag vertonen dan hun leeftijdsgenoten met lager opgeleide ouders (Hypothese 1).

De gezinssamenstelling is een andere belangrijke factor voor de ontwikkeling en het gedrag van een kind. Kinderen met getrouwde of samenwonende ouders kunnen profiteren van het feit dat ouders hun competenties en gezinstijd kunnen bundelen (Brown et al., 1990; Sayer, Bianchi \& Robinson, 2004). In het algemeen zijn kinderen uit gebroken en eenoudergezinnen 'slechter af'. Ze vertonen vaker afwijkend en risicovol gedrag dan kinderen uit tweeoudergezinnen (McLanahan \& Sandefur, 1994; Dornbusch e.a., 1985). Dit kan komen door stress of door financiële problemen, maar ook door het feit dat de ouders minder tijd hebben voor hun kind. Uit onderzoek blijkt dat kinderen uit eenoudergezinnen vaker digitale technologieën gebruiken dan hun leeftijdsgenoten uit tweeoudergezinnen (Notten e.a., 2009; Sonck \& De Haan, 2011). Maar er wordt in eenoudergezinnen ook minder tijd besteed aan de begeleiding van het mediagebruik (Notten \& Kraaykamp, 2009a; Warren, 2005). Hieruit volgt de verwachting dat kinderen uit eenoudergezinnen meer online risicogedrag vertonen dan kinderen uit tweeoudergezinnen (Hypothese 2). 


\subsection{Ouderlijke internetbegeleiding en online risicogedrag}

Ook of zelfs wanneer de sociaaleconomische kenmerken van gezinnen gelijk zijn, verschillen ouders in hun opvoedstrategieën en de manier waarop ze het internetgebruik van hun kinderen begeleiden. Niet elke ouder geeft evenveel aandacht en steun aan zijn of haar kind. Ook het aantal regels binnen een gezin, de striktheid hiervan en de controle erover zijn verschillend. In het algemeen geldt dat ondersteuning en geborgenheid, gecombineerd met een bepaalde mate van regels en toezicht in het gezin, positief doorwerken op de ontwikkeling van kinderen, en de kans op (toekomstig) deviant gedrag verkleinen. Het tegengestelde is ook empirisch vastgesteld: ineffectief opvoedgedrag, zoals verwaarlozing of inconsistent zijn, vergroot de kans dat het kind (later) onaangepast gedrag vertoont (Baumrind 1991; Steinberg e.a., 1994; Patterson, DeBaryshe \& Ramsey, 1990; Hoeve e.a., 2009). Voortbordurend op deze algemene aspecten van opvoeden en de diverse vormen van ouderlijke televisiebegeleiding (Valkenburg e.a., 1999), worden ook verschillende typen ouderlijke internetbegeleiding onderscheiden (Livingstone \& Helsper, 2008; Kirwil, 2009; Sonck, Nikken \& De Haan, 2013; Nikken en Jansz, 2013). Ten eerste worden 'instructieve' vormen van ouderlijke internetbegeleiding onderscheiden, zoals actieve en sociale begeleidingsvormen van het gebruik van internet. Ten tweede passen ouders ook 'restrictieve' en controlerende vormen van internetbegeleiding toe: bijvoorbeeld het stellen van regels en restricties voor internetgebruik, het controleren van het gebruik, en het instellen van technische restricties in de vorm van filters en software.

Instructieve mediabegeleiding door ouders wordt gekenmerkt door interactie tussen ouder en kind over het gebruik. Deze actieve en sociale vormen van mediabegeleiding hebben in het algemeen als doel het mediagebruik, de mediavaardigheden en het begrip van de inhoud te verbeteren, zodat het kind er voordeel van kan hebben (Kirwil, 2009; Lobe e.a., 2011; Sonck, Nikken \& De Haan, 2013). Door hun kinderen te leren verantwoord om te gaan met media dragen ouders in belangrijke mate bij aan het welzijn van hun kinderen (Notten, Kraaykamp \& Tolsma, 2013). Zo geven kinderen die thuis hebben geleerd dat privacy belangrijk is, niet zo gemakkelijk persoonlijke gegevens prijs op het internet (De Souza \& Dick, 2009; Liu, Ang \& Lwin, 2013). De verwachting is daarom dat actieve en sociale vormen van ouderlijke internetbegeleiding zorgen voor minder online risicogedrag van adolescenten (Hypothese 3).

Het doel van restrictieve begeleiding is doorgaans om ongewenst gedrag van kinderen te voorkomen of te verminderen. Eerder onderzoek heeft laten zien dat ouderlijk toezicht en ouderlijke restricties in verband staan met een lagere mate van delinquent en normovertredend gedrag, zowel online als offline (Leung \& Lee, 2011; Steinberg e.a., 1994). 
Een belangrijke voorspeller van online risicogedrag is de hoeveelheid tijd die wordt besteed aan online media (Livingstone \& Helsper, 2010; Lobe e.a, 2011). De restricties die ouders opleggen over zowel de tijd die online wordt doorgebracht als de inhoud die mag worden bekeken, zijn zeer effectief gebleken in het verminderen van een reeks online risico's (Lee, 2013; Livingstone \& Helsper, 2008; Mitchell, Finkelhor \& Wolak, 2003). De verwachting is daarom dat restrictieve begeleiding van ouders, dus het stellen van regels voor internetgebruik, het monitoren van het gebruik en het toepassen van technische restricties (zoals een filter) online risicogedrag van adolescenten voorkomt, of in elk geval de kans erop verkleint (Hypothese 4).

Omdat de intensiteit van de ouderlijke begeleiding kan veranderen als het kind ouder wordt (Clark, 2011), richt deze studie zich specifiek op adolescenten van 11 tot en met 16 jaar oud, waarbij rekening wordt gehouden met leeftijdsverschillen binnen deze groep.

\subsection{Landkenmerken, online risicogedrag en ouderlijke internetbegeleiding}

Toegang tot en gebruik van internet verschilt tussen gezinnen, maar ook tussen landen (Lobe et al., 2011; Notten e.a., 2009). Daarnaast blijken effecten van de mediaopvoeding en het mediaklimaat binnen een gezin te variëren tussen landen (Kirwil, 2009; Notten \& Kraaykamp, 2009b). Uit eerdere beschrijvende studies blijkt dat de kans dat kinderen in risicovolle online situaties terechtkomen, samenhangt met contextuele factoren, zoals de mate waarin breedbandinternet en internetaansluitingen aanwezig zijn in een land (Hasebrink e.a., 2008; Lobe e.a., 2011). Om mogelijke schijnverbanden te vermijden worden in dit onderzoek de invloed van gezinskenmerken en de mate van internetverspreiding in een land op het online risicogedrag van adolescenten simultaan onderzocht. Omdat ouders verschillend omgaan met het internetgedrag van hun kinderen, zowel door kenmerken op individueel als op landniveau, wordt in deze studie ook onderzocht in hoeverre de invloed van de internetbegeleiding van ouders op het onlinerisicogedrag van jongeren samenhangt met de digitale ontwikkeling van een land.

In landen waar internet wijder verspreid is, dus waar meer mensen internet gebruiken, brengen kinderen meer tijd online door dan in landen met een lager niveau van digitale ontwikkeling (Livingstone e.a., 2011b). In een samenleving met meer internetgebruikers zijn er waarschijnlijk ook meer mogelijkheden tot gebruik van digitale media (Lobe e.a., 2011); thuis, op school, bij vrienden thuis en door de mobiele applicaties ook onderweg. Omdat de sociale omgeving een belangrijke voorspeller is van risicogedrag van jongeren (Jessor, 1991) en omdat de hoeveelheid tijd die wordt doorgebracht op het internet in verband

2013, JAARGANG 88, NR. 4 
staat met online risico's (Livingstone \& Helsper, 2010; Sonck \& De Haan, 2011), stimuleert een sociale omgeving waar internetgebruik meer voorkomt wellicht het experimenteren met online gedrag en het nemen van online risico's. Daarom is de verwachting dat in landen met een hoger niveau van internetverspreiding adolescenten meer online risicogedrag vertonen (Hypothese 5).

Het niveau van modernisering van een land blijkt van belang voor de internetbegeleiding die ouders hanteren (Kirwil, 2009; Lobe e.a., 2011; Paus-Hasebrink e.a., 2013). Dit onderzoek veronderstelt dat ook de invloed van de ouderlijke internetbegeleiding varieert tussen landen met een verschillend niveau van internetverspreiding. In moderne digitaal ontwikkelde en veelal kennisgebaseerde samenlevingen, wordt toegang en gebruik van internet meer gefaciliteerd en gestimuleerd, op de werkplek maar bijvoorbeeld ook in openbare bibliotheken en op school (Lobe e.a., 2011). Wanneer er meer mensen online zijn, inclusief onderwijzers en leeftijdsgenoten, worden digitale kennis en vaardigheden wijder verspreid, ook of vooral buitenshuis. Vanuit dit moderniseringsperspectief (Treiman, 1970; zie ook Chiu \& McBride-Chang, 2010) is de verwachting dat internetbegeleiding binnen het gezin minder belangrijk wordt bij het bijsturen van risicovol internetgedrag van adolescenten in meer gedigitaliseerde samenlevingen (Hypothese 6).

Aan de andere kant zijn ouders uit landen die digitaal verder ontwikkeld zijn, zich meer bewust van de gevaren en de mogelijkheden die internet met zich meebrengt (Lobe e.a., 2011). Mogelijk zullen in deze landen ouders juist vaker instructieve en beperkende maatregelen toepassen. De rol van ouders en hun opvoedingsactiviteiten, met name die gericht op 'gezond' internetgebruik, zullen belangrijker zijn in samenlevingen waar internettoegang en het digitale aanbod vrijwel ongelimiteerd is. Ouders kunnen dan onderscheidend zijn, hetgeen aansluit bij het sociale reproductieperspectief (Bourdieu, 1984; Shavit \& Blossfeld, 1993). Evenals dat in meer ontwikkelde samenlevingen een literaire opvoeding van groter belang is voor de ontwikkeling van kinderen (Notten \& Kraaykamp, 2009b; Park, 2008), zou dit ook zo kunnen zijn voor ouderlijke internetbegeleiding. De contrasterende verwachting is dan dat in meer digitaal ontwikkelde samenlevingen, waar online gebruik plaatsvindt op diverse locaties, in diverse vormen en waar de digitale netwerken van adolescenten uitgebreid zijn, internetbegeleiding binnen het gezin juist belangrijker wordt bij het voorkomen of limiteren van online risicogedrag van adolescenten (Hypothese 7). De focus van dit onderzoek is op de relatie tussen de mate van digitalisering in een samenleving en het online risicogedrag van jongeren, waarbij rekening wordt gehouden met het algemene opleidingsniveau van een land. 


\section{Data, meetinstrumenten en methode}

\section{I Data}

De onderzoeksvraag wordt beantwoord met enquêtegegevens afkomstig uit het 'EU Kids Online II'-project, verzameld in 2010. Het doel van het EU Kids Online-project is het vergroten van kennis over ervaringen en gedragingen wat betreft risicovol en veilig gebruik van online technologieën. In de EU Kids Online-dataset staat informatie over huishoudens, ouderlijke internetbegeleiding en online activiteiten, afkomstig van kinderen van 9 tot en met 16 jaar (die internet gebruiken) en hun ouders in 25 Europese landen. ${ }^{2}$ De steekproeftrekking vond stapsgewijs plaats, uiteindelijk is per geselecteerd huishouden één jongere en één ouder geselecteerd. Zie www.eukidsonline.net voor meer informatie over de dataverzameling en het project. ${ }^{3}$

Voor dit onderzoek zijn adolescenten tussen 11 en 16 jaar geselecteerd (18.709 respondenten). Het bewust opzoeken van online risico's is nauwelijks aan de orde bij kinderen van 9 en 10 jaar, hetgeen ook blijkt uit het hoge percentage missende waarden (26\%) op de afhankelijke variabele online risicogedrag in deze leeftijdsgroep. Voor deze studie zijn de EU Kids Online-gegevens gecombineerd met gegevens op landniveau afkomstig van Eurostat (2012) en UNESCO (2012). Omdat in dit onderzoek cross-sectionele gegevens worden gebruikt, moeten resultaten en uitspraken over causaliteit met voorzichtigheid worden geïnterpreteerd.

\subsection{Meetinstrumenten}

Online risicogedrag

In de EU Kids Online-enquête hebben jongeren vragen beantwoord over risicovolle online activiteiten, naar voorbeeld van het 'UK Children Go Online-survey' (zie Livinstone e.a., 2011a): 'Heb je het afgelopen jaar één van de volgende dingen gedaan op het internet; indien ja, hoe vaak heb je elk van deze dingen gedaan?': (i) gezocht naar nieuwe vrienden op het internet; (ii) persoonlijke informatie (bijv. mijn echte naam, adres of telefoonnummer) gestuurd naar iemand die ik nog nooit persoonlijk ontmoet heb; (iii) mensen toegevoegd als vriend (bijv. via Hyves) die ik nog nooit persoonlijk ontmoet heb; (iv) me voorgedaan als iemand anders op het internet; (v) een foto of video van mijzelf gestuurd naar iemand die ik nog nooit in het echt ontmoet heb. De antwoordcategorieën waren (0) 'nooit/niet in het afgelopen jaar', (1) 'minder dan één keer per maand', (2) 'één of twee keer per maand', (3) 'één of twee keer per week', (4) 'elke dag of bijna elke dag’. Er is een schaal gemaakt voor online risicogedrag

2013, JAARGANG 88, NR. 4 
door het gemiddelde te nemen van de vijf items, met een range van 0 tot $4(\alpha=.76)(6,6 \%$ missende waarden $) .4$

\section{Gezinskenmerken}

Met de variabele opleidingsniveau ouders is het hoogste opleidingsniveau van de ouders (vader of moeder) gemeten, lopend van (0) 'geen of alleen basisonderwijs' tot (6) 'postdoctoraal', in lijn met de 'International Standard Classification of Education' (ISCED) (0,4\% missend). De gezinssamenstelling bestaat uit twee vormen: (0) 'tweeoudergezin' of (1) 'eenoudergezin'. Andere mogelijke gezinssamenstellingen $(0,9 \%)$ zijn buiten beschouwing gelaten.

\section{Ouderlijke internetbegeleiding}

De EU Kids Online-dataset bevat vijf verschillende concepten voor internetbegeleiding (zie Livingstone e.a., 2011a). Voorgaand onderzoek heeft ouderlijke internetbegeleiding zowel vanuit het perspectief van het kind als de ouder bestudeerd en voor beide benaderingen zijn voor- en nadelen vastgesteld. Hier is gekozen voor het ouderperspectief, mede omdat begeleidingsvormen zoals het achteraf controleren door ouders van het internetgebruik van hun kind, waarschijnlijk niet of minder zichtbaar zijn voor het kind zelf. Omdat de items over internetbegeleiding gedichotomiseerd zijn is voor het vaststellen van de verschillende vormen van internetbegeleiding een confirmatieve principale factoranalyse uitgevoerd (obliek geroteerd; de dimensies correleren >.3), op basis van een polychorische correlatiematrix. In Appenix B staan de bijbehorende factorladingen en communaliteiten weergegeven. De factoranalyse geeft weer dat er sprake is van een tweetal dubbelladers. Wanneer deze buiten beschouwing gelaten worden, bestaat de vierde dimensie uit drie items die verwijzen naar 'samen internetgebruik', en kunnen in totaal vijf beleidingsvormen worden onderscheiden. Tenzij anders vermeld, waren de antwoordcategorieën voor alle afzonderlijke items: (0) 'nee' en (1) 'ja'.

Samen internetgebruik is gemeten met de volgende vragen over activiteiten die ouders soms met hun kinderen ondernemen: (i) naast hem/ haar zitten terwijl hij/zij het internet gebruikt; (ii) in de buurt blijven als hij/zij internet gebruikt; (iii) samen dingen doen op het internet. Er is een schaal gemaakt door het gemiddelde te nemen over alle drie de items $(\alpha=.62)(0,4 \%$ missend). Voor alle schalen geconstrueerd op basis van dichotome variabelen is in dit onderzoek de betrouwbaarheid gemeten door middel van de Kuder-Richardson Formule 20 (1937).

Actieve begeleiding van veilig internetgebruik is gemeten met zes vragen aan ouders in hoeverre zij de volgende activiteiten met hun kind hebben ondernomen: (i) geholpen wanneer hij/zij iets moeilijk vond of niet kon vinden op het internet, (ii) uitgelegd waarom sommige websites goed of 
slecht zijn, (iii) hem/haar geadviseerd hoe het internet veilig te gebruiken, (iv) hem/haar suggesties gegeven over hoe je te gedragen tegenover anderen op het internet, (v) geholpen wanneer hij/zij door iets van slag was door iets gezien op het internet, (vi) praten met het kind over wat te moet doen als iets op het internet hem/haar van streek maakt of verontrust $(\alpha=.82)(0,4 \%$ missende waarden). De variabele restrictieve internetbegeleiding, in de vorm van ouderlijke internetregels, is gemeten door aan ouders te vragen of het kind de volgende zes online activiteiten mag doen, de antwoordcategorieën daarbij waren (0) 'altijd' of (1) 'alleen met toestemming of nooit': (i) chatten/msn; (ii) muziek of films downloaden; (iii) online filmpjes bekijken (bijv. YouTube); (iv) een eigen profiel hebben op sociale netwerksite(s) (bijv. Facebook); (v) persoonlijke informatie gegeven aan anderen op het internet; (vi) foto's, filmpjes of muziek uploaden en delen met anderen. Er is een schaal gemaakt door het gemiddelde te nemen over alle zes de items $(\alpha=.83)$ (1,6\% missend). Het monitoren van internetgebruik is gemeten door aan ouders te vragen of zij achteraf de volgende vier vormen van het internetgebruik van hun kind controleren of bekijken: (i) websites die het kind heeft bezocht; (ii) e-mailberichten of msn-berichten van hun kind (iii) het profiel van het kind op een sociale netwerksite of online community; (iv) vrienden of contacten die het kind heeft toegevoegd op sociale netwerksites $(\alpha=.82)(9,3 \%$ missend). De variabele technologische restricties is gemaakt met behulp van vragen naar het gebruik in huis van het volgende: (i) sofware of andere mogelijkheden om sommige websites te blokkeren of inhoud te filteren, (ii) sofware of andere mogelijkheden om bij te houden welke websites uw kind bezoekt, (iii) een dienst of een contract om de tijd dat $u$ kind online is te limiteren, (iv) software om spammail en virussen te voorkomen. Er is een schaal gemaakt door het gemiddelde te nemen van deze vier items $(\alpha=.59)\left(9,4 \%\right.$ missend). ${ }^{5}$

Voorgaand onderzoek heeft aangetoond dat de mediaconsumptie van ouders van invloed is op het mediagebruik van hun kind, maar ook op het type en de mate van ouderlijke mediabegeleiding (Lee, 2013; Notten \& Kraaykamp, 2009a). In het huidige onderzoek wordt daarom ook rekening gehouden met de mate van internetgebruik van de ouders. De variabele frequentie internetgebruik ouders geeft aan in welke mate ouders internet gebruiken: (0) 'nooit' (1) 'minder dan één of twee keer per maand', (2) 'één of twee keer per maand', (3) 'één of twee keer per week', (4) 'elke dag of bijna elke dag' ( $0,5 \%$ missend).

\section{Individuele controlevariabelen}

Zowel de frequentie waarmee kinderen gebruikmaken van internet als hun online vaardigheden staan in verband met het ervaren van online risico's (Livingstone \& Helsper, 2010; Sonck \& De Haan, 2011). Dit onder- 
zoek controleert daarom voor beide aspecten. De variabele frequentie internetgebruik adolescent geeft aan hoe vaak het adolescente kind gebruikmaakt van internet: (0) 'minder dan één of twee keer per maand', (1) 'één of twee keer per maand', (2) 'één of twee keer per week', (3) 'elke dag of bijna elke dag’ (0,3\% missend). De internetvaardigheden van de adolescent zijn gemeten door de mate men in staat is de volgende activiteiten uit te voeren: (i) diverse websites vergelijken om te zien welke informatie waar is; (ii) veranderen van filterinstellingen, zodat je zelf kunt bepalen welke sites je wel en niet kunt bezoeken (iii) een website toevoegen aan je favorieten (iv) blokkeren van ongewenste advertenties en/of junkmail en spam (v) je geschiedenis verwijderen (vi) de privacy-instellingen van je sociaal-netwerkprofiel wijzigen (vii) berichten blokkeren van mensen waar je niets van wil horen (viii) informatie vinden over hoe je het internet veilig kunt gebruiken $(\alpha=.82)$. Antwoordcategorieën waren (0) 'nee' en (1) 'ja'.

Tot slot wordt in dit onderzoek rekening gehouden met de leeftijd (range: 11-16 jaar) en het geslacht van de respondenten $(1=$ vrouw). Deze factoren zijn belangrijk gebleken bij het verklaren van verschillen in internetgebruik en het ervaren van online risico's bij jongeren, en ouderlijke internetbegeleiding (Notten e.a., 2009; Peter \& Valkenburg, 2006; Sonck, Nikken \& De Haan, 2013).

Kenmerken op landniveau

De variabele internetverspreiding geeft het percentage inwoners van een land weer dat wekelijks gebruikmaakt van internet, gemeten in het jaar voorafgaand aan het onderzoek (2009) (Eurostat, 2012). Omdat verschillende metingen van internetgebruik en aanwezigheid ervan in een land (bijv. aantal breedbandaansluitingen, percentage huishoudens met toegang tot internet) sterk correleren (Lobe e.a., 2011), kan het percentage frequente internetgebruikers ook gezien worden als een indicator voor het niveau van ICT-ontwikkeling binnen een land. Dit onderzoek houdt rekening met het algemene opleidingsniveau van een land, gemeten door het verwachte aantal jaren opleiding in 2010 (UNESCO, 2012). Deze indicator representeert een algemener niveau van modernisering van een land (zie bijv. Lobe e.a., 2011; Notten e.a., 2009). Beide landkenmerken zijn voor opname in de analyse gecentreerd naar het gemiddelde. Zie Appendix A voor meer gedetailleerde informatie over de landkenmerken.

Ten slotte zijn respondenten met een missende waarde op een van de variabelen verwijderd, wat resulteert in een uiteindelijke dataset met 15.415 respondenten. In tabel 1 staan de beschrijvende statistieken weergegeven. 
Tabel 1 Beschrijvende gegevens

\begin{tabular}{|c|c|c|c|c|}
\hline & Gemiddelde & Std. Dev. & Min & Max \\
\hline Online risicogedrag & 0,49 & 0,64 & 0,00 & 4,00 \\
\hline \multicolumn{5}{|l|}{ Individueel niveau (niveau I) } \\
\hline \multicolumn{5}{|l|}{ Gezinskenmerken } \\
\hline Ouderlijk opleidingsniveau & 3,52 & 1,40 & 0,00 & 6,00 \\
\hline Eenouder gezin & 0,21 & & 0,00 & 1,00 \\
\hline \multicolumn{5}{|l|}{ Ouderlijke internetbegeleiding } \\
\hline Samen internetgebruiken & 0,49 & 0,36 & 0,00 & 1,00 \\
\hline $\begin{array}{l}\text { Actieve begeleiding van veilig } \\
\text { internetgebruik }\end{array}$ & 0,64 & 0,33 & 0,00 & 1,00 \\
\hline Restrictieve internetbegeleiding & 0,43 & 0,32 & 0,00 & 1,00 \\
\hline Monitoren van internetgebruik & 0,39 & 0,39 & 0,00 & 1,00 \\
\hline Technologische restricties & 0,33 & 0,27 & 0,00 & 1,00 \\
\hline \multicolumn{5}{|l|}{ Controle variabelen } \\
\hline Leeftijd adolescent & 13,57 & 1,68 & 11,00 & 16,00 \\
\hline Geslacht adolescent (I=vrouw) & 0,50 & & 0,00 & 1,00 \\
\hline Frequentie internetgebruik adolescent & 2,78 & 0,47 & 0,00 & 3,00 \\
\hline Internetvaardigheden adolescent & 0,62 & 0,31 & 0,00 & 1,00 \\
\hline Frequentie internetgebruik ouders & 3,11 & 1,40 & 0,00 & 4,00 \\
\hline \multicolumn{5}{|l|}{ Land niveau (niveau 2) } \\
\hline $\begin{array}{l}\text { Internetverspreiding } \\
\text { (\% internetgebruikers) }(62=0)\end{array}$ & 0,00 & 16,65 & $-31,63$ & 26,37 \\
\hline Opleidingsniveau (jaren) $(16=0)$ & 0,00 & 1,10 & $-4,05$ & 2,05 \\
\hline
\end{tabular}

\subsection{Methoden en modellen}

Om inzicht te kunnen krijgen in de relatie tussen gezinskenmerken, internetverspreiding binnen een land en het nemen van online risico's door adolescenten zijn verschillende multiniveaumodellen geschat. Door het toepassen van multiniveau-analyse wordt rekening gehouden met de hiërarchische structuur binnen de EU Kids Online-dataset; adolescenten (individueel niveau) genest in 25 verschillende Europese landen (land niveau). Met deze methode kunnen gelijktijdig effecten van zowel individuele als landkenmerken op het vertonen van online risicogedrag worden geschat. Dit zorgt voor nauwkeurigere schattingen van de landkenmerken dan wanneer geen rekening wordt gehouden met de geneste structuur (Snijders \& Bosker, 1999).

De verschillende multiniveau-modellen zijn weergegeven in tabel 2 . Model 0 is het lege model. In model 1 zijn alle controlevariabelen en gezinskenmerken opgenomen. In model 2 is de ouderlijke internetbegeleiding toegevoegd en in model 3 zijn de landkenmerken opgenomen (fixed effecten). Tabel 3 geeft de waarden weer van de geschatte cross- 
level-interacties tussen een specifiek type ouderlijke internetbegeleiding (individueel niveau; random effect) en de internetverspreiding binnen een land (landniveau). Met behulp van deze cross-level interacties is getest of de effecten van ouderlijke begeleiding op online risicogedrag van adolescenten verschillen tussen landen met een verschillend niveau van digitalisering. Vanwege collineariteit en non-convergentie van het model was het niet mogelijk om alle cross-level-interacties tegelijkertijd op te nemen.

\section{Resultaten}

In tabel 2 staan de resultaten van de multiniveau-regressiemodellen. De resultaten van het nulmodel (model 0) laten zien dat online risicogedrag significant varieert tussen landen, maar de verschillen worden voornamelijk verklaard op het individuele niveau (gezinskenmerken en kenmerken van het kind); slechts een beperkt deel van de verklaarde variantie is op landniveau (ICC $=0,035$ ).

Uit model 1 blijkt dat adolescenten met hoger opgeleide ouders minder online risicogedrag vertonen dan hun leeftijdsgenoten met lager opgeleide ouders $(b=-0,028)$. Dit is in overeenstemming met de verwachting (hypothese 1 ). In lijn met hypothese 2 blijkt dat adolescenten die opgroeien in een eenoudergezin, vaker online risicogedrag vertonen dan hun leeftijdsgenoten uit tweeoudergezinnen $(b=0,038)$. Deze uitkomst is in lijn met eerder onderzoek naar de invloed van het opgroeien in een eenoudergezin op deviant gedrag. In model 1 zijn ook de controle variabelen op het individuele niveau opgenomen. Het blijkt dat oudere adolescenten en jongens vaker online risicogedrag vertonen (respectievelijk, $b=0,038$ en $b=-0,033$ ). Verder wijzen de resultaten uit dat adolescenten die meer tijd online doorbrengen en over meer online vaardigheden beschikken ook vaker riskante online activiteiten ondernemen (respectievelijk $\mathrm{b}=0,114$ en $\mathrm{b}=0,288$ ). Tot slot laten de resultaten van model 1 zien dat wanneer ouders bekender zijn met het gebruik van internet hun adolescente kinderen minder online risicogedrag vertonen $(\mathrm{b}=-0,008)$.

In model 2 zijn de vijf onderscheiden vormen van ouderlijke internetbegeleiding opgenomen, naast de gezinskenmerken en controlevariabelen. Uit de resultaten blijkt dat samen internetgebruiken resulteert in minder online risicogedrag van adolescenten. Adolescenten vertonen dus minder online risicogedrag wanneer hun ouders in de directe omgeving zijn en betrokken zijn bij hun internetgebruik $(b=-0,039)$, hetgeen in overeenstemming is met hypothese 3 . Wanneer ouders restricties hanteren, door het opstellen van regels voor het gebruik van internet, vertonen hun adolescente kinderen minder vaak online risicogedrag 


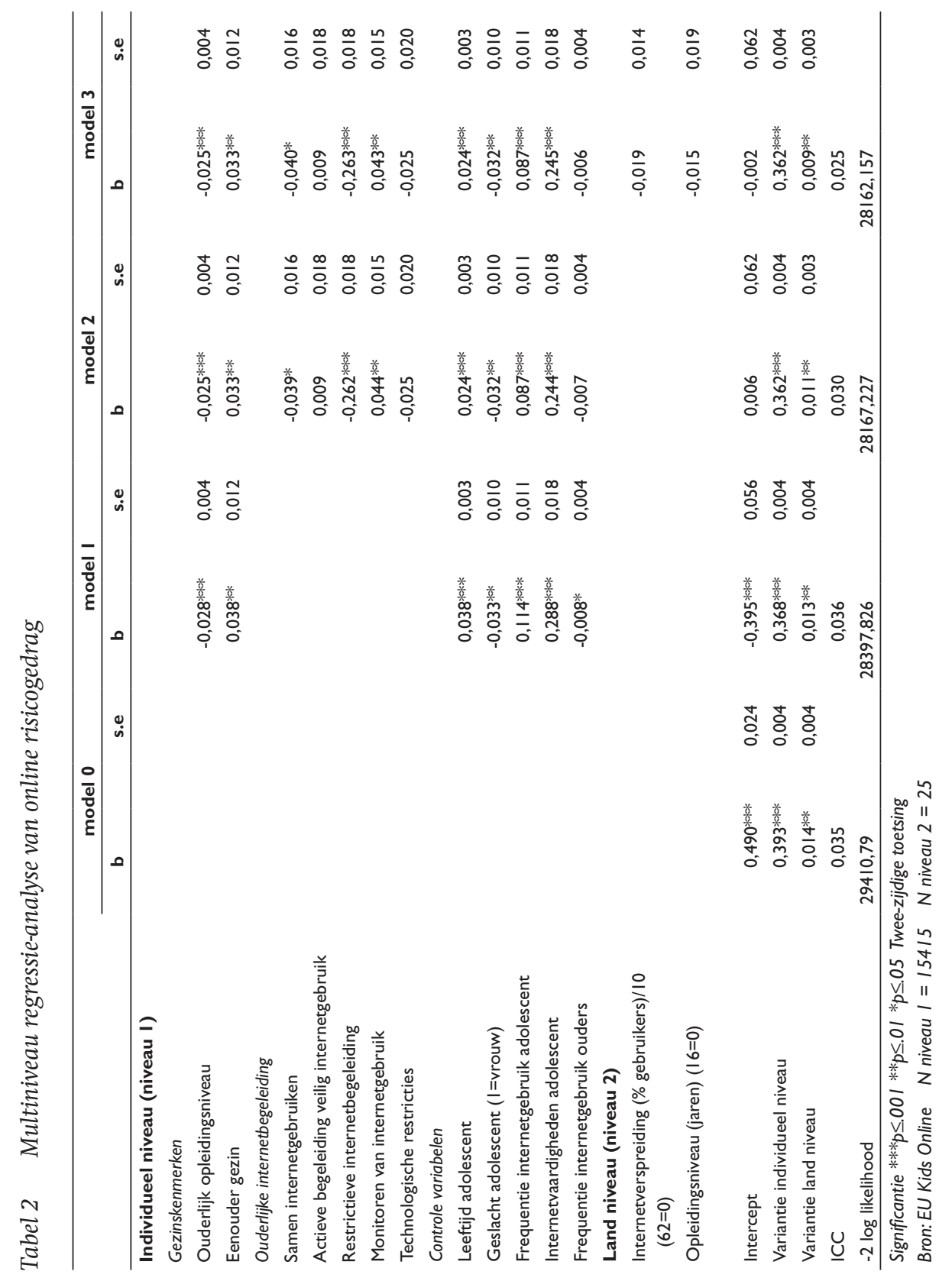

2013, JAARGANG 88, NR. 4 
dan wanneer ouders dat niet doen $(b=-0,262)$ (bevestiging hypothese 4). Opmerkelijk en in tegenstelling tot de verwachting is de positieve relatie tussen het ouderlijk monitoren van internetgebruik (i.e., ouderlijke controle) en online risicogedrag van adolescenten $(b=0,044)$. Het is onwaarschijnlijk dat het controleren van de internetactiviteiten van het kind leidt tot meer risicogedrag. Het is waarschijnlijker dat deze positieve relatie weergeeft dat als adolescenten roekeloos zijn in hun internetgedrag, ouders hun controle op de online activiteiten van hun kind verscherpen (zie ook Kalmus, Blinka \& Olafsson, 2013). Wanneer rekening wordt gehouden met alle andere factoren blijken ouderlijke actieve begeleiding van veilig internetgebruik en technologische restricties geen invloed te hebben op het risicogedrag van adolescenten. Uit model 2 blijkt ook dat de invloed van het opleidingsniveau van de ouders en het opgroeien in een eenoudergezin niet veel kleiner wordt wanneer de ouderlijke internetbegeleiding wordt toegevoegd aan de analyse. Deze bevindingen suggereren dat ouderlijke internetbegeleiding een succesvolle methode is om de online activiteiten van adolescenten te beinvloeden, min of meer ongeacht de sociale herkomst en samenstelling van het gezin.

In model 3 zijn de landkenmerken toegevoegd. Uit de resultaten kan worden opgemaakt dat de mate van digitalisering en het onderwijsniveau van een land geen significante invloed hebben op het nemen van online risico's door adolescenten. Dus, in tegenstelling tot de verwachting (hypothese 5), heeft het percentage internetgebruikers binnen een land geen invloed op het online risicogedrag van 11- tot 16-jarige adolescenten.

Tabel 3 geeft de resulaten weer van de modellen met cross-levelinteracties. Uit de resultaten van model 3a blijkt dat de invloed van samen internetten minder sterk is naarmate de digitale verspreiding in een land groter is $(b=0,020)$. Dit betekent dat in landen waar mensen vaker gebruikmaken van het internet, het samen internetgebruiken door ouders en hun adolescente kinderen minder succesvol is bij het terugdringen van online risicogedrag (bevestiging hypothese 6). Uit de resultaten van model $3 \mathrm{~d}$ blijkt dat in landen met meer internetgebruikers de positieve invloed van ouderlijke controle toeneemt $(b=0,022)$. Het lijkt erop dat ouders vaker de online activiteiten van adolescenten controleren in landen met een grotere internetverspreiding, en dit is in lijn met hypothese 7. Alle andere cross-level-interacties zijn niet significant. Dit betekent dat het niveau van digitalisering in een land geen invloed heeft op de relaties die bestaan tussen ouderlijke begeleiding gericht op veiligheid, het stellen van internetregels en technologische restricties aan de ene kant en online risicogedrag van adolescenten aan de andere kant. De resultaten suggereren ook dat, ongeacht de mate van 


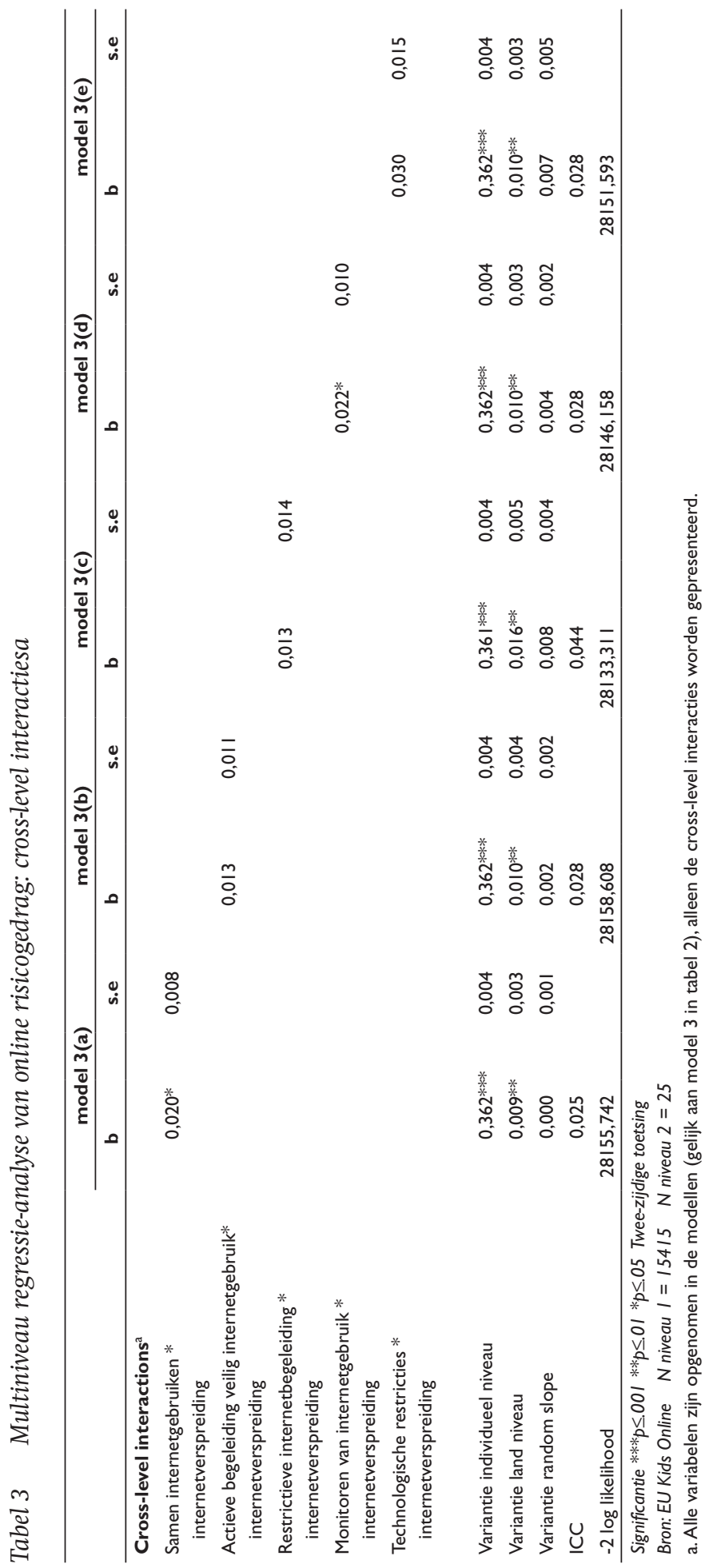


internetverspreiding in een land, ouderlijke restricties voor internetgebruik zeer effectief zijn bij het voorkomen of verkleinen van het online risicogedrag van adolescenten.

\section{Conclusie en discussie}

Internet is niet meer weg te denken uit de Europese samenleving van nu. Niet voor ouders en zeker niet voor hun adolescente kinderen. Het internet is een waardevolle bron voor informatie en communicatie, maar het gebruik ervan brengt ook risico's met zich mee. Dit onderzoek heeft zich gericht op het online risicogedrag van adolescenten. Het eerste doel van deze studie was te bekijken in hoeverre het nemen van online risico's samenhangt met de sociale achtergrond van ouders, de begeleiding die ouders hun kinderen bieden bij het internetgebruik en het niveau van digitalisering in een land. Het tweede doel was om te achterhalen of de invloed van ouderlijke internetbegeleiding op online risicogedrag varieert tussen landen met een verschillend niveau van digitalisering. De onderzoeksvragen zijn beantwoord met behulp van de EU Kids Onlinedataset, met daarin gegevens van 15.415 adolescenten uit 25 landen.

Deze studie leidt tot vier belangrijke conclusies. Ten eerste blijkt dat gezinskenmerken zowel in positieve als negatieve zin van invloed zijn. Adolescenten met lager opgeleide ouders en uit eenoudergezinnen vertonen vaker online risicogedrag dan hun leeftijdsgenoten uit meer 'bevoorrechte' huishoudens. Deze kwetsbare groep adolescenten en hun ouders verdienen daarom aanhoudend aandacht binnen ondersteunende beleidsprogramma's, ook als het gaat om internetgebruik.

De tweede belangrijke conclusie is dat ouderlijke internetbegeleiding een wezenlijke invloed uitoefent op het online risicogedrag van adolescenten. Met name restrictieve internetbegeleiding is effectief bij het verminderen van online risicogedrag van jongeren. Door het hanteren van regels voor internetgebruik verkleinen ouders de kans dat hun adolescente kinderen online risicovol gedrag gaan vertonen. Ook wanneer ouders samen internetgebruiken met hun kinderen, kunnen zij online risicogedrag voorkomen, of op zijn minst de kans daarop verkleinen. Verder lijken de resultaten te suggeren dat als kinderen in het verleden al eens risicovol gedrag hebben vertoond, ouders vaker hun online activiteiten controleren.

Ten derde blijkt het vertonen van risicogedrag op internet niet af te hangen van het niveau van digitalisering van een land. Dit betekent dat beleidsmakers succesvoller zijn in het verminderen van online risicogedrag wanneer zij zich primair richten op de directe sociale omgeving van adolescenten.

De vierde en laatste conclusie is dat de invloed van de ouderlijke 
internetbegeleiding op online risicogedrag van adolescenten varieert tussen landen met een verschillend niveau van digitalisering. In landen waar meer mensen online zijn, heeft het samen internetgebruiken door ouder en kind minder invloed als het gaat om verminderen van online risicogedrag. Het verband tussen ouderlijke controle en risicovol online gedrag neemt toe wanneer het gebruik van internet vanzelfsprekender is. Dit sluit mogelijk aan bij de toenemende zorg die ouders in digitaal ontwikkelde landen hebben over het toenemende internetgebruik van hun kinderen. Bovenal blijkt dat het stellen van regels binnen het gezin over internetgebruik een essentiële rol speelt bij het verminderen van riskant online gedrag, ongeacht het niveau van digitalisering in een land. In moderne samenlevingen waar de stijl van opvoeden vaak wat vrijer is, zouden ouders aangemoedigd kunnen worden om (meer) regels te stellen voor internetgebruik. Hierbij is het natuurlijk wenselijk dat rekening wordt gehouden met de kansen die internet biedt.

In dit onderzoek is bekeken wat de invloed is van verschillende contextuele factoren op het online risicogedrag van adolescenten. Dit is gedaan met cross-sectionele gegevens. De conclusies in deze studie moeten daarom met de nodige voorzichtigheid worden geïnterpreteerd. Dat geldt met name voor de causaliteit in de relatie tussen ouderlijke begeleiding en online risicogedrag van kinderen. Een ander belangrijk discussiepunt is de relatie tussen de internetbegeleiding van ouders en de leeftijd van het kind. Ouders stellen hun wijze van opvoeden vaak bij als hun kinderen ouder worden. Hoewel dit onderzoek hiermee rekening houdt, zou toekomstig onderzoek verder kunnen differentiëren naar leeftijd. Daarnaast blijkt uit deze studie dat ouders vaker de internetactiviteiten van hun kind controleren wanneer deze al eerder riskant gedrag heeft vertoond. Maar wat ouders precies doen met de verzamelde informatie is onduidelijk. Omdat het monitoren en controleren van het internetgedrag van adolescenten evidenter lijkt te zijn in digitaal meer ontwikkelde landen, is onderzoek naar deze vorm van ouderlijke begeleiding en de mogelijke toepassing daarvan relevant.

Naar verwachting zal het gebruik van internet en digitale applicaties alleen maar toenemen de komende jaren. De bevindingen uit dit onderzoek kunnen voor beleidsmakers, docenten en opvoeders een extra stimulans zijn om ouders ervan te overtuigen dat betrokkenheid bij internetgebruik van hun kinderen belangrijk is. Het is daarnaast van belang te onderkennen dat adolescenten uit minder stabiele of problematische gezinnen vatbaarder zijn voor risicogedrag, inclusief riskante gedragingen online. Internet wordt steeds mobieler en neemt een almaar groeiende plaats in op scholen. Dat is een goede reden om ook docenten en jeugdwerkers te mobiliseren om actiever te worden in het begeleiden van kinderen en jongeren bij hun online activiteiten. 


\section{Noten}

1. Dr. Natascha Notten, vakgroep Sociologie, Radboud Universiteit Nijmegen. Contactgegeven: Postbus 9104, 6500 HE Nijmegen. Email: N.Notten@maw.ru.nl, voor meer informatie zie www.nnotten.nl

2. Landen opgenomen in de EU Kids Online-dataset: Oostenrijk, België, Bulgarije, Cyprus, Tsjechië, Denemarken, Estland, Finland, Frankrijk, Griekenland, Duitsland, Hongarije, Ierland, Italië, Litouwen, Nederland, Noorwegen, Polen, Portugal, Roemenië, Slovenië, Spanje, Zweden, Turkije en het Verenigd Koninkrijk.

3. Dit artikel is gemaakt met behulp van het EU Kids Online-netwerk, gesubsidieerd door de European Commission (DG Information Society) Safer Internet Programme (project code SIP-KEP-321803). Zie www.eukidsonline.net

4. De variabele 'online risicogedrag' is scheef verdeeld. Additionele toetsten op robuustheid hebben echter laten zien dat via logistische modellering dezelfde resultaten worden verkregen.

5. Het blokkeren van ongewenste advertenties en spam is onderdeel van de internetvaardigheden van adolescenten in dit onderzoek. Daarom is item (iv) opgenomen in de schaal technische retricties, hoewel de betrouwbaarheid van deze schaal hoger is (.65) zonder dit item. Voor de bevindingen van dit onderzoek heeft het geen significante implicaties.

\section{Literatuur}

Bandura, A. (1977). Social Learning Theory. New York: General Learning Press.

Baumrind, D. (1991). The influence of parenting style of adolescent competence and substance use. Journal of Early Adolescence, 11, p. 56-95.

Bronfenbrenner, U. (1979). The Ecology of Human Development. Experiments by Nature and Design. Cambridge, MA: Harvard University Press.

Bourdieu, P. (1984). Distinction: A Social Critique of the Judgement in Taste. London: Routledge.

Brown, J.D., Childers, K.W., Bauman, K.E. \& Koch, G.G. (1990). The influence of new media and family structure on young adolescents' television and radio use. Communication Research, 17, p. 65-82.

Chiu, M.M. \& C. McBride-Chang (2010). Family and reading in 41 countries: Differences across cultures and students. Scientific Studies of Reading, 14, p. 514-543

Clark, L.S., Demont-Heinrich, C. \& Webber, S. (2005). Parents, ICTs, and children's prospects for success: Interviews along the digital 'Access rainbow'. Critical Studies in Media Communication, 22, p. 409-426.

Clark, L.S., (2011). Parental mediation theory for the digital age. Communication theory, 21, p. 323-343.

Deursen, A. van, Van Dijk, J.A. \& Peeters, O. (2011). Rethinking internet skills. The contribution of gender, age, education, internet experience, and hours online to medium- and content-related internet skills. Poetics, 39, p. 125-144. 
D'Haenens, L. (2001). Old and new media: Access and ownership in the home. In S. Livingstone en M. Bovill (Red.), Children and Their Changing Media Environment: A European comparative study (p. 53-84). Mahwah, New Jersey: Lawrence Erlbaum Associates.

De Souza, Z. \& Dick, G.N. (2009). Disclosure of information by children in social networking- Not a case of "you show me yours and I'll show you mine". International Journal of Information Management, 29, 255-261

DiMaggio, P., Hargittai, E., Celeste, C. \& Shafer, S. (2004). Digital Inequality: From unequal access to differentiated use. In K. Neckerman, K. (Red.). Social Inequality (p. 355-400), New York: Rusell Sage Foundation.

Dornbusch, S.M., Carlsmith, J.M., Bushwall, S.J., Ritter, P.L., Leiderman, H. Hastorf, A.H., \& Gross, R.T. (1985). Single parents, extended households, and the control of adolescents. Child Development, 56, p. 326-341

Eurostat (2012). Information retrieved in July 2012 via http://appsso.eurostat.ec.europa.eu/nui/show.do?dataset=isoc_ci_ifp_iuandlang=en

Fogel, J. \& Nehmad, E. (2009). Internet social network communities: Risk taking, trust, and privacy concerns. Computers in Human Behavior 25, p. $153-160$

Görzig, A. \& Ólafsson, K. (2013). What makes a bully a cyberbully? Unraveling the characteristics of cyberbullies across 25 European countries. Journal of Children and Media, 7, p. 9-27.

Hargittai, E. (2010). Digital Na(t)ives? Variation in Internet Skills and Uses among Members of the "Net Generation". Sociological Inquiry, 80, p. 92-113.

Hasebrink, U., Livingstone, S., Haddon, L. \& Ólafsson, K. (eds) (2008) Comparing Children's Online Opportunities and Risks Across Europe: Cross-national Comparisons for EU Kids Online (2nd edn). London: LSE, EU Kids Online (http://eprints.lse.ac.uk/24368/)

Hoeve, M., Semon Dubas, J., Eichelsheim, V.I., Van der Laan, P.H., Smeenk, W. \& J.R.M. Gerris (2009). The Relationship Between Parenting and Delinquency: A Meta-analysis. J Abnorm Child Psychol, 37, p. 749-775

Jessor, R. (1991) Risk behavior in adolescence: a psychosocial framework for understanding and action. Journal of Adolescent Health 12, p. 597-605.

Kalmus, V., Blinka, L. \& Ólafsson, K (2013). Does it matter what mama says: Evaluating the role of parental mediation in european adolescents' excessive internet use. Children and Society. Access online.

Kirwil, L. (2009). Parental mediation of children's internet use in different European countries. Journal of Children and Media, 3, p. 394-409.

Kuder, G.F. \& Richardson, M.W. (1937). The theory of the estimation of test reliability. Psychometrika, 2, p. 151-160.

Lee, S.J. (2013). Parental restrictive mediation of children's internet use: effective for what and for whom? New Media en Society, 15, p. 466-481.

Lenhart, A., Purcell, K., Smith, A., \& Zickuhr, K. (2010). Social Media and 
Mobile Internet Use Among Teens and Young Adults. Pew Interet en American Life Project.

Leung, L. \& Lee. P.S.N. (2011). The influence of information literacy, internet addiction and parenting styles on internet risks. New Media and Society, 14, p. 117-136.

Liu, C., Ang, R.P., \& Lwin, M.O. (2013). Cognitive, personality and social factors associated with adolescents' online personal information disclosure. Journal of Adolescence, 36, p. 629-638.

Livingstone, S. \& Helsper, E. (2008). Parental mediation of children's internet use. Journal of Broadcasting and Electronic Media, 52, p. 581-599.

Livingstone, S. \& Helsper, E. (2010). Balancing opportunities and risks in teenagers' use of the internet: The role of online skills and self-efficacy. New Media en Society, 12, p. 309-329.

Livingstone, S., Haddon, L., Görzig, A. \& Ólafsson, K. (2011a). Technical Report and User Guide: The 2010 EU Kids Online Survey. LSE, London: EU Kids Online.

Livingstone, S., Haddon, L., Görzig, A. \& Ólafsson, K. (2011b). Risks and Safety on the Internet: The Perspective of European Children. Full Findings. LSE, London: EU Kids Online.

Lobe, B., Livingstone, S., Ólafsson, K. \& Vodeb, H. (2011). Cross-national Comparison of Risks and Safety on the Internet: Initial Analysis from the EU Kids Online Survey of European Children, EU Kids Online, Deliverable D6. EU Kids Online Network, London, UK.

McLanahan, S. \& Sandefur, G. (1994). Growing up with a Single Parent. What Hurts, what Helps. Cambridge: Harvard University Press.

Mitchell, K., Finkelhor, D. \& Wolak, J. (2003). The exposure of youth to unwanted sexual material on the internet. A national survey of risk, impact and prevention. Youth and Society, 34, p. 330-358

Nikken, P. \& Jansz, J. (2013). Developing scales to measure parental mediation of young children's internet use. Learning, Media and Technology. Access online.

Notten, N. \& Kraaykamp, G. (2009a). Parents and the media. A study of social differentiation in parental media socialization. Poetics, 37, p. $185-200$.

Notten, N. \& Kraaykamp, G. (2009b). Home media and science performance: A cross-national study. Educational Research and Evaluation, 15, p. 367-384.

Notten, N., Kraaykamp, G. \& J. Tolsma (2013). Parents, television and children's weight status. Journal of Children and Media, 7, p. 235-252.

Notten, N., Peter, J., Kraaykamp, G. \& Valkenburg, P. M. (2009). Research Note: Digital divide across borders - A cross-national study of adolescents' use of digital technologies. European Sociological Review, 25, p. 551-560. 
Park, H. (2008). Home Literacy Environments and Children's Reading Performance: A Comparative Study of 25 Countries. Educational Research and Evaluation, 14, p. 489-505.

Pasquier, D. (2001). Media at Home: Domestic Interactions and Regulation. In S. Livingstone en M. Bovill (Red.), Children and their Changing Media Environment: A European Comparative Study (p. 161-177). Mahwah, New Jersey: Lawrence Erlbaum Associates.

Patterson, G.R., Debaryshe, B. \& Ramsey, E. (1990). A developmental perspective on antisocial behavior. American Psychologist, 44, p. 329-335.

Paus-Hasebrink, I., Bauwens, J., Dürager, A.E. \& C. Ponte (2013). Exploring types of parent-child relationship and internet use across Europe. Journal of Children and Media, 7, p. 114-132.

Peter, J. \& Valkenburg, P. (2006). Adolescents' exposure to sexually explicit material on the internet. Communication Research, 33, p. 178-204.

Rockman, I.F. 2002. Strengthening connections between information literacy, general education and assessment efforts. Library Trends, 51, p. 185-198.

Sayer, L.C., Bianchi, S.M. \& Robinson, J.P. (2004). Are parents investing less in children? Trends in mothers' and fathers' time with children. American Journal of Sociology, 110, p. 1-43.

Shavit, Y. \& Blossfeld, H.P. (1993). Persistent Inequality. Changing educational attainment in thirteen countries, Boulder, CO: Westview.

Sonck, N. \& De Haan, J. (2011). Kinderen en internetrisico's. EU Kids Online onderzoek onder 9-16-jarige internetgebruikers in Nederland. Den Haag, Sociaal en Cultureel Planbureau.

Sonck, N., Nikken. P. \& De Haan, J. (2013). Determinants of internet mediation: a comparison of the reports by Dutch parents and children. Journal of Children and Media, 7, p. 96-113.

Snijders, T.A.B. \& Bosker, R.J. (1999). Multiniveau Analysis. An Introduction to Basic and Advanced Multiniveau Modeling. Londen: Sage Publications.

Steinberg, L., Lamborn, S.D., Darling, N., Mounts, N.S. \& Dornbusch, S.M. (1994). Over-time changes in the adjustment and competence among adolescents from authoritative, authoritarian, indulgent, and neglectful families. Child Development, 65, p. 754-770.

Treiman, D.J. (1970). Industrialisation and social stratification. In E.O. Laumann (Red.) Industrialization and Social Stratification Research and Theory for the 1970s (p. 207-234). Bobbs-Merill, Indianapolis.

UNESCO (2012). UNESCO Institute for Statistics (2012). http://stats.uis. unesco.org, (zie ook http://hdr.undp.org/en/media/HDR_2010_EN_Tables_reprint.pdf)

Valkenburg, P.M. (2004). Children's Responses to the Screen. Mahwah, NJ: Lawrence Erlbaum Associates.

Valkenburg, P.M., Krcmar, M., Peeters, A.L. \& Marseille, N.M. (1999). Devel-

2013, JAARGANG 88, NR. 4 
oping a scale to assess three styles of television mediation: "instructive mediation," "restrictive mediation", and "social coviewing". Journal of Broadcasting and Electronic Media, 43, p. 53-66.

372 Valkenburg, P.M. \& Peter, J. (2011). Online communication among adolescents: An integrated model of its attraction, opportunities, and risks. Journal of Adolescent Health, 48, p. 121-127.

Walraven A., Brand-Gruwel S. \& Boshuizen, H.P.A. (2009) How students evaluate information and sources when searching the World Wide Web for information. Computers en Education, 52, p. 234-246.

Warren, R. (2005). Parental mediation of children's television viewing in low-income families. Journal of Communication, 55, p. 847-863.

Appendix A: Landkenmerken

\begin{tabular}{lcccc}
\hline N & $\begin{array}{c}\text { Online risico } \\
\text { gedrag (gemid.) }\end{array}$ & $\begin{array}{c}\text { Internet } \\
\text { verspreiding (\%) }\end{array}$ & $\begin{array}{c}\text { Opleidingsniveau } \\
\text { (jaren) }\end{array}$ \\
\hline Oostenrijk & 586 & 0,51 & 67 & 15,00 \\
Belgie & 633 & 0,44 & 70 & 15,90 \\
Bulgarije & 638 & 0,53 & 40 & 13,70 \\
Cyprus & 581 & 0,56 & 45 & 13,80 \\
Tsjechie & 672 & 0,58 & 54 & 15,20 \\
Duitsland & 696 & 0,47 & 71 & 15,60 \\
Denemarken & 660 & 0,38 & 82 & 16,90 \\
Estland & 668 & 0,71 & 67 & 15,80 \\
Griekenland & 475 & 0,49 & 38 & 16,50 \\
Spanje & 607 & 0,22 & 54 & 16,40 \\
Finland & 728 & 0,41 & 79 & 17,10 \\
Frankrijk & 587 & 0,45 & 65 & 16,10 \\
Hungarije & 577 & 0,33 & 57 & 15,30 \\
lerland & 617 & 0,38 & 60 & 17,90 \\
Italie & 648 & 0,57 & 42 & 16,30 \\
Litouwen & 578 & 0,73 & 55 & 16,00 \\
Nederland & 722 & 0,39 & 86 & 16,70 \\
Norwegen & 738 & 0,40 & 88 & 17,30 \\
Polen & 626 & 0,40 & 52 & 15,20 \\
Portugal & 561 & 0,48 & 42 & 15,50 \\
Roemenie & 584 & 0,70 & 31 & 14,80 \\
Zweden & 705 & 0,57 & 56 & 15,60 \\
Slovenie & 707 & 0,58 & 30,80 \\
Turkije & 229 & 0,58 & & 16,90 \\
Verenigd Koninkrijk & 592 & 0,41 & 58 &
\end{tabular}

Bron: EU Kids Online $\quad \mathrm{N}$ level $I=15415 \quad \mathrm{~N}$ level $2=25$ 
Appendix B: Geroteerde factorladingen (patroon matrix) en unieke varianties

\begin{tabular}{|c|c|c|c|c|c|c|}
\hline & Factor I & Factor 2 & Factor 3 & Factor 4 & Factor 5 & $\begin{array}{c}\text { Unieke } \\
\text { variantie }^{\mathrm{a}}\end{array}$ \\
\hline $\begin{array}{l}\text { met kind praten over wat hij/zij doet } \\
\text { op het internet }\end{array}$ & 0,375 & & & 0,402 & & 0,482 \\
\hline $\begin{array}{l}\text { naast het kind zitten terwijl hij/zij het } \\
\text { internet gebruikt }\end{array}$ & & & & 0,723 & & 0,438 \\
\hline $\begin{array}{l}\text { in de buurt blijven als het kind } \\
\text { internet gebruikt }\end{array}$ & & & & 0,589 & & 0,551 \\
\hline $\begin{array}{l}\text { kind aanmoedigen om zelfstanding } \\
\text { dingen te ontdekken op het } \\
\text { internet }\end{array}$ & 0,333 & & & 0,429 & & 0,652 \\
\hline samen dingen doen op het internet & & & & 0,545 & & 0,520 \\
\hline kind mag chatten/msn & & & 0,829 & & & 0,304 \\
\hline kind mag muziek of films downloaden & & & 0,796 & & & 0,353 \\
\hline $\begin{array}{l}\text { kind mag online filmpjes en videoclips } \\
\text { bekijken }\end{array}$ & & & 0,894 & & & 0,195 \\
\hline $\begin{array}{l}\text { kind mag een eigen profiel hebben op } \\
\text { sociale netwerksite(s) }\end{array}$ & & & 0,898 & & & 0,233 \\
\hline $\begin{array}{l}\text { kind mag persoonlijke informatie } \\
\text { gegeven aan anderen op het } \\
\text { internet }\end{array}$ & & & 0,680 & & & 0,462 \\
\hline $\begin{array}{l}\text { kind mag foto's, filmpjes of muziek } \\
\text { uploaden en delen met anderen }\end{array}$ & & & 0,833 & & & 0,293 \\
\hline $\begin{array}{l}\text { geholpen wanneerkind iets moeilijk } \\
\text { vond of niet kon vinden op het } \\
\text { internet }\end{array}$ & 0,566 & & & & & 0,524 \\
\hline $\begin{array}{l}\text { kind uitgelegd waarom sommige } \\
\text { websites goed of slecht zijn }\end{array}$ & 0,760 & & & & & 0,307 \\
\hline $\begin{array}{l}\text { kind geadviseerd hoe het internet } \\
\text { veilig te gebruiken }\end{array}$ & 0,782 & & & & & 0,303 \\
\hline $\begin{array}{l}\text { kind suggesties gegeven over hoe je } \\
\text { te gedragen tegenover anderen op } \\
\text { het internet }\end{array}$ & 0,798 & & & & & 0,296 \\
\hline $\begin{array}{l}\text { kind geholpen wanneer hij/zij door } \\
\text { iets van slag was door iets gezien } \\
\text { op het internet }\end{array}$ & 0,771 & & & & & 0,467 \\
\hline $\begin{array}{l}\text { praten met het kind over wat te } \\
\text { moet doen als iets op het internet } \\
\text { hem/haar van streek maakt }\end{array}$ & 0,853 & & & & & 0,292 \\
\hline $\begin{array}{l}\text { achteraf controleren welke websites } \\
\text { het kind heeft bezocht }\end{array}$ & & 0,661 & & & & 0,297 \\
\hline $\begin{array}{l}\text { achteraf controleren van } \\
\text { e-mailberichten of msn-berichten } \\
\text { van hun kind }\end{array}$ & & 0,817 & & & & 0,257 \\
\hline $\begin{array}{l}\text { actheraf controleren van het profiel } \\
\text { van het kind op een sociale } \\
\text { netwerksite of online community }\end{array}$ & & 0,907 & & & & 0,180 \\
\hline $\begin{array}{l}\text { actheraf controleren welke vrienden } \\
\text { of contacten het kind heeft } \\
\text { toegevoegd op sociale netwerksites }\end{array}$ & & 0,927 & & & & 0,140 \\
\hline
\end{tabular}

2013, JAARGANG 88, NR. 4 
Factor I Factor 2 Factor 3 Factor 4 Factor 5 Unieke

\begin{tabular}{|c|c|c|}
\hline & & variantie $^{a}$ \\
\hline gebruik van sofware of andere & 0,838 & 0,296 \\
\hline \multicolumn{3}{|l|}{ mogelijkheden om sommige } \\
\hline \multicolumn{3}{|l|}{ websites te blokkeren of inhoud } \\
\hline \multicolumn{3}{|l|}{ te filteren } \\
\hline gebruik van sofware of andere & 0,809 & 0,221 \\
\hline \multicolumn{3}{|l|}{ mogelijkheden om bij te houden } \\
\hline \multicolumn{3}{|l|}{ welke websites uw kind bezoekt } \\
\hline gebruik van een dienst of een & 0,620 & 0,603 \\
\hline \multicolumn{3}{|l|}{ contract om de tijd dat uw kind } \\
\hline \multicolumn{3}{|l|}{ online is te limiteren } \\
\hline gebruik van software om spam mail & 0,472 & 0,694 \\
\hline en virusen te voorkomen & & \\
\hline
\end{tabular}

Ladingen $<.3$ niet gepresenteerd

a unieke variantie $=\mathrm{I}$ - communaliteit 